\title{
Ethnoichthyology and fishery aspects of persons inhabiting fishery communities at Mochima National Park, Sucre State, Venezuela
}

\section{Etnoictiología y aspectos pesqueros de grupos humanos que habitan comunidades pesqueras del Parque Nacional Mochima, Estado Sucre, Venezuela}

\author{
Ruiz-Velásquez, L. ${ }^{1}$, Fariña, A. ${ }^{2 *}$, Rojas, M. ${ }^{3}$, Alió, J. ${ }^{3}$. \\ 1 Universidad de Oriente, Venezuela. \\ 2Universidad de Oriente (UDO), Laboratorio de Ecología de Peces Marinos, Departamento de \\ Biología, Escuela de Ciencias. Núcleo de Sucre, UDO. Estado Sucre, Venezuela. \\ ${ }^{3}$ Universidad de Oriente, Venezuela.
}

\begin{abstract}
A B S T R AC T
Ethnoichthyological studies are aimed to identify and record the relationships between human beings and fish. This type of studies are commonly performed in fishery communities with limited access to services, which increases their dependence to the biological realm surrounding them. Studies like this are scarce in Venezuela, hence their importance to record and preserve valuable information on popular traditions. The present study evaluated the ethnoichthyological knowledge of persons inhabiting fishery communities in Mochima National Park (MNP), aiming to prepare a written record that guarantees its preservation in time. Semistructured surveys were applied to a group of 214 persons. From them, $65.63 \%$ practiced fishing as the main economic activity. In the zone, a total of 35 fish species were quoted as fishing targets. A group of 24 fish species had medicinal use and 28 species had diverse uses. Several of the quoted uses have not been previously recorded in the literature and belong to popular knowledge. They represent important contributions to the maintenance of the cultural traditions of inhabitants of fishery communities of MNP.
\end{abstract}

Article Info/Información del artículo

Received/Recibido: August 30 2016.

Accepted/Aceptado: April 6 2017.

\author{
R E S U M E N
}

Los estudios etnoictiológicos tienen como finalidad identificar y reportar las relaciones establecidas entre los seres humanos y los peces. Esta clase de estudios se suelen realizar en comunidades pesqueras con acceso limitado a los servicios, lo cual aumenta su dependencia con el entorno biológico. En Venezuela son escasos los trabajos de este tipo, por lo que son importantes para registrar y preservar la información sobre tradiciones populares. El presente estudio evaluó el conocimiento etnoictiológico que poseen los pobladores de comunidades pesqueras ubicadas en el Parque Nacional Mochima (PNM), con el propósito de dejar un registro escrito que garantice su preservación en el tiempo. Para ello se aplicaron cuestionarios semi estructurados a 214 personas. De estas, el $65.63 \%$ practica la pesca como actividad económica principal. Se citaron para la zona 35 especies de peces como principal objetivo de pesca. Se reportaron 24 especies de peces con usos medicinales y 28 especies con usos diversos. Muchos de los usos citados no se encuentran registrados en la literatura consultada y forman parte del conocimiento popular. Estos constituyen un aporte importante al sostenimiento del acervo cultural de los pobladores de las comunidades pesqueras del PNM.

*Corresponding Author:

Fariña Pestano, Angel Rafael, Universidad de Oriente (UDO), Laboratorio de Ecología de Peces Marinos, Departamento de Biología, Escuela de Ciencias. Núcleo de Sucre, UDO. Estado Sucre, Venezuela. Phone: 0293-40024560414-3832376 E-mail.: afarina46@yahoo.com 


\section{K E Y W OR D S}

Ethnobiology, limited service access, medicinal use, popular knowledge.

\section{Introduction}

Ethnoicthyology can be defined as the scientific study of the cultural relationships established between human species and fishes (Costa-Neto, 2001). Depending on the society, time and location, interac- tions of human beings with fishes can be appreciated diversely, such as: ludic, as when individuals have fun by attending beta fishes (Betta splendens) competencies; trophic, when fishes are part of human feeding; medicinal, when corporal parts or products extracted from fishes are used to heal some illness; sexual, when man uses ichthyic fauna to obtain carnal pleasure; religious, when these animals are used with a sacred meaning; commercial; artisan; esthetic-ornamental, amongst others (Nascimiento and Costa-Neto, 2005).

The traditional practices of cure using fishing resources have been mainly transmitted from generation to generation, and usually orally (Costa-Neto, 1999). The use of ichthyic resources in traditional medical resources has been documented in several localities. For example, Branch and Silva (1983) cite six fish species used in traditional Amazonian medicine. Begossi and Braga (1992) studied feeding taboos and the relation of fishes with popular medicine among fishermen of the River Tocantins. (cited by: Nascimento and Costa-Neto, 2005), recorded the use of eight species by the inhabitants of Várzea de Marituba, in São Francisco de Alagoas, Brazil.

Among the researches performed on the non-medicinal uses of fishes, in general ethnoicthyology, highlights the work of The (2002) whom analized the fihisng activity of fishery communities in Rio São Francisco (MG) and verified the existence of local rules for control on access and time of use of fishes, which directly regulates the exploitation and conservation of these resources. Other works performed in Brazil emphasized ecological and fishes behavior aspects. Silvano y Begossi (2002) verified knowledge of fishermen of Rio Piracicaba on the biology and behavior of fishes. Souza and BarreIla (2001) analyzed the knowledge of artisanal fishermen in the Ecological Station of Juréia Itatins, related

\section{P A L A B R A S C L V E}

etnobiología, comunidades pesqueras, servicios limitados, usos medicinales, conocimiento popular.

\section{Introducción}

La etnoictiología puede ser definida como el estudio científico de las relaciones culturales establecidas entre la especie humana y los peces (Costa-Neto, 2001). Dependiendo de la sociedad, de la época y de la localidad, las interacciones de los seres humanos con los peces pueden ser apreciadas de diversas maneras, tales como: lúdica, por ejemplo cuando los individuos se divierten asistiendo a competencias de peces beta (Betta splendens); trófica, cuando los peces forman parte de la alimentación; medicinal, cuando partes corporales o productos extraídos de los peces son utilizados para sanar alguna dolencia; sexual, cuando el hombre se vale de fauna íctica o de derivados de esta para obtención de placer carnal; religioso, cuando esos animales son empleados con un significado sagrado; comercial; artesanal; estético-ornamental, entre otros (Nascimiento y Costa-Neto,2005).

Las prácticas tradicionales de cura empleando recursos pesqueros han sido principalmente transmitidas de generación en generación, y comúnmente por vía oral (Costa-Neto, 1999). El empleo de recursos ícticos en sistemas médicos tradicionales ha sido documentado en varias localidades. Por ejemplo, Branch y Silva (1983) citan seis especies de peces utilizadas en la medicina tradicional amazónica. Begossi y Braga (1992) estudiaron los tabúes alimenticios y la relación de los peces con la medicina popular entre los pescadores de Río Tocantins. (citado por: Nascimento y Costa-Neto, 2005), registró el uso de ocho especies de peces por los moradores de Várzea de Marituba, en el bajo de São Francisco de Alagoas, Brasil.

Entre las investigaciones realizadas sobre usos no medicinales de los peces, en etnoictiología general, destaca el trabajo de Thé (2002), quien analizó la actividad pesquera de las comunidades de pescadores de Rio São Francisco (MG) y verificó la existencia de reglas locales para el control sobre el acceso y el tiempo de utilización de los peces, lo que regula directamente la explotación y conservación de estos recursos. Otros trabajos realizados en Brasil, hicieron énfasis en aspectos ecológicos y de comportamiento de los peces. Silvano y Begossi (2002) verificaron el conocimiento de los pescadores de Río Piracicaba sobre la biología y el comportamiento de los peces. Souza y Barrella (2001) analizaron el conocimiento de los pescadores artesa- 
to habitat, trophic ecology and spatial sdistribution of fishes, and compared local population ethnoknowledge to scientific literature.

In Venezuela, studies made in ethnoicthyology are scarce, and few those recorded that correspond to studies made in indigenous communities that operate in continental waters. Such is the case of two works from Royero (1989, 1994): the first contributed to knowledge on the Piaroa ethnoicthyology (Dearuwa), acknowledging the name of 77 fishes and their parts, and the classification systems this ethnicity applies; and the second, consisted in aspects of ethnoicthyology and natural history of the Yanomami from the high river Siapa and the Mavaca River, in the Amazonas, presenting 100 names of fishes in Yanomami language and compared to scientific names. The only work published with this type of investigation in fishery communities (except for records of indigenous names of fishes by Novoa, 2000), which practically live of fishery, is Fariña et al., (2011) in the Paria Peninsula. Hence, the importance of continuing studies in this area, since fishery communities constitutes an essential source of knowledge that could help to better comprehend the natural mean, and the collection of benefits for man. In addition, the information granted by the people is part of their culture, constituting a social asset of high value that deserves preservation. The present study evaluated the ethnoichthyological knowledge and fishing aspects of human groups inhabiting fishery communities in Mochima National Park (MNP), State of Sucre.

\section{Study area}

The Mochima National Park (MNP) is an area under special management regime, decreed in 1973, with a surface of 94935 ha, located in the nororiental region of Venezuela (10 9' $50^{\prime \prime}$ and $10^{\circ} 26^{\prime} 0^{\prime \prime}$ $\mathrm{N}$; and $64^{\circ} 13^{\prime} 20^{\prime \prime}$ and $64^{\circ} 47^{\prime} 32^{\prime \prime} \mathrm{O}$ ). Apart from terrestrial areas, it includes an important marine portion that covers $52 \%$ of its surface (INPARQUES, 1982). Climate in the park is warm towards coastal zones, with an average annual temperature of $26.6^{\circ} \mathrm{C}$ (between 24.8 and $27.5^{\circ} \mathrm{C}$ ) and average annual precipitation according to the altitudinal tiers: $250 \mathrm{~mm}$ in the islands, $500 \mathrm{~mm}$ in the coastal zone and more than $2,000 \mathrm{~mm}$ in the mountainous zones. Rainy season takes place from May to October, August being the month with most rainfall, although rain peak is extended to October in the higher nales de la Estación Ecológica de Juréia Itatins, en relación al hábitat, ecología trófica y distribución espacial de los peces, y compararon el etnoconocimiento de la población local con la literatura científica.

En Venezuela, los trabajos realizados en etnoictiología han sido escasos, y los pocos de los que se tiene registro corresponden a estudios hechos en comunidades indígenas que faenan en aguas continentales. Tal es el caso de dos trabajos de Royero (1989, 1994): el primero contribuyó al conocimiento de la etnoictiología Piaroa (Dearuwa), dando a conocer 77 nombres de peces y de sus partes, al igual que los sistemas de clasificación que esta etnia aplica; y el segundo consistió en aspectos de la etnoictiología y la historia natural de los Yanomami del alto río Siapa y río Mavaca, en el estado Amazonas, presentando 100 nombres de peces en idioma Yanomami y los comparó con nombres científicos. El único trabajo publicado con ese tipo de investigación en comunidades marino-costeras (salvo registros de nombres indígenas de los peces por Novoa, 2000), las cuales prácticamente viven de la pesca, es el de Fariña et al., (2011) en la Península de Paria. De allí, la importancia de continuar estudios en esta área, ya que las comunidades de pescadores constituye una fuente esencial de conocimientos que podrían ayudar a la comprensión del medio natural así como a la obtención de beneficios para el hombre. Además, la información otorgada por los pobladores forma parte de su cultura, constituyendo un bien social de alto valor que amerita ser preservado. En el presente estudio se evaluaron el conocimiento etnoictiológico y los aspectos pesqueros de los grupos humanos que habitan comunidades pesqueras en el Parque Nacional Mochima, Estado Sucre.

\section{Área de estudio}

El Parque Nacional Mochima (PNM) es un área bajo régimen de administración especial, decretado en 1973, con una superficie de 94935 ha, ubicado en la región nororiental de Venezuela ( $10^{\circ}$ 9' $50^{\prime \prime}$ y $10^{\circ} 26^{\prime} 0^{\prime \prime} \mathrm{N}$; y $64^{\circ}$ $13^{\prime} 20^{\prime \prime}$ y $64^{\circ} 47^{\prime} 32$ " O). Además de las zonas terrestres, incluye una importante porción marina que abarca el $52 \%$ de su superficie (INPARQUES, 1982). El clima en el parque es cálido hacia las zonas de costa, con una temperatura media anual de $26.6{ }^{\circ} \mathrm{C}$ (entre 24.8 y $27.5 \stackrel{\circ}{\circ} \mathrm{C}$ ) y precipitación media anual variable según el piso altitudinal: $250 \mathrm{~mm}$ en las islas, $500 \mathrm{~mm}$ en la zona costera y más de 2,000 $\mathrm{mm}$ en las zonas montañosas. La estación lluviosa es de mayo a octubre siendo agosto el mes con mayor pluviosidad, aunque el pico de lluvias se extiende hasta octubre enlas 
zones of the park (PARKSWATCH, 2004). The maritime part includes a variety of islands and islets, Isla de la Borracha and attached islets are the most occidental; while the most oriental are Islas Caracas, north from the Santa Fe locality, and west from the Manare peninsula, in the State of Sucre. This archipelago is formed by three islands very close to each other, which are, from east to west: Venado, Caracas del Este and Caracas del Oeste or Caraquitas. Caracas del Oeste is the largest from the group, with a length of $3.7 \mathrm{~km}$, and the one representing a major diversity of environments, while the other two islands, have a similar structure but with less diversity of environments. Caracas Islands are populated by fishery communities, most of which inhabit permanently in the zone, even though there are also temporal inhabitants that attend for fishing operations in certain times (Cervigón and Gasparini, 1989), these islands were studied totally (all localities). In addition to Islas Caracas, two fishing communities located in the Peninsula of Santa Fe, La Morena and El Congrio, took part as study area, since they are the most populated (according to previous visits to the zone).

\section{Materials and Methods}

\section{Data collection}

A previously made, semi-structured questionnaire was used as tool for data collection.

The fishery communities object of this study were: Corocorero, Playa Piedra (Isla Venados), La Anegada, El Mangle, Puerto Escondido de la Anegada, Don Jacinto, Morro Blanco (Caracas del Este), El Indio, Cruza las Patas, Playa May, Carenero and El Avance (Caracas del Oeste), in addition to El Congrio and La Morena in the Peninsula of Santa Fe. In each of these localities, semi-structured questionnaires on aspects on fishery and the usefulness of fishes were made to the inhabitants of both genres, older than 10 years, who were present in the study area during samplings. The identification of the species of fishes named by the inhabitants was made with the help of photographs from captures, as well as pictures in books of Venezuela fishes (Cervigón, 1991, 1993, 1994, 1996; Cervigón and Alcalá, 1999) and in the guide of Human and Deloach (2002). In the cases in which fishes were not clearly identified with the help of photographs, fishermen were requested zonas más altas del parque (PARKSWATCH, 2004). La parte marítima incluye una variedad de islas e islotes, siendo las más occidentales la isla de la Borracha y sus islotes anexos; mientras que las más orientales son las islas Caracas, al norte de la población de Santa Fe y al oeste de la península de Manare, en el Estado Sucre. Este archipiélago está formado por tres islas muy juntas entre sí, que de este a oeste son: Venado, Caracas del Este y Caracas del Oeste o Caraquitas. Caracas del Oeste es la más grande del grupo, con una longitud de $3.7 \mathrm{~km}$, y la que presenta una mayor diversidad de ambientes; mientras que las otras dos islas, Caracas del Este y Venado, tienen una estructura similar pero con menos diversidad de ambientes. Las Islas Caracas están pobladas por comunidades de pescadores, la mayoría de las cuales habitan de manera permanente en la zona, aún cuando hay también pobladores temporales que acuden para las faenas de pesca en determinadas épocas (Cervigón y Gasparini, 1989), estas islas fueron estudiadas en su totalidad (todas las localidades). Adicionalmente a las Islas Caracas, se tomó como parte del área de estudio dos comunidades pesqueras ubicadas en la Península de Santa Fe, estas fueron: La Morena y El Congrio ya que son de las más pobladas (según visitas previas a la zona).

\section{Materiales y Métodos}

\section{Toma de datos}

Para la obtención de datos se empleó como herramienta un cuestionario semi estructurado, elaborado previamente.

Las comunidades de pescadores objeto de estudio fueron: Corocorero, Playa Piedra (Isla Venados), La Anegada, El Mangle, Puerto Escondido de la Anegada, Don Jacinto, Morro Blanco (Caracas del Este), El Indio, Cruza las Patas, Playa May, Carenero y El Avance (Caracas del Oeste), además de El Congrio y La Morena en la Península de Santa Fé. En cada una de estas localidades se realizaron cuestionarios semi estructurados sobre aspectos de pesquerías y utilidad de los peces, a los habitantes de ambos sexos mayores de 10 años que se encontraron presentes en el área de estudio durante los muestreos. La identificación de las especies de peces nombrados por los pobladores, se realizó con la ayuda de fotografías producto de las capturas, así como las ilustraciones presentes en los libros de los peces de Venezuela (Cervigón, 1991, 1993, 1994, 1996; Cervigón y Alcalá, 1999) y en la guía de Human y Deloach (2002). En los casos en los que con ayuda de las fotografías no se pudieron identificar claramente los peces, se solicitó a los pescadores que facilitaran al menos dos ejemplares, los 

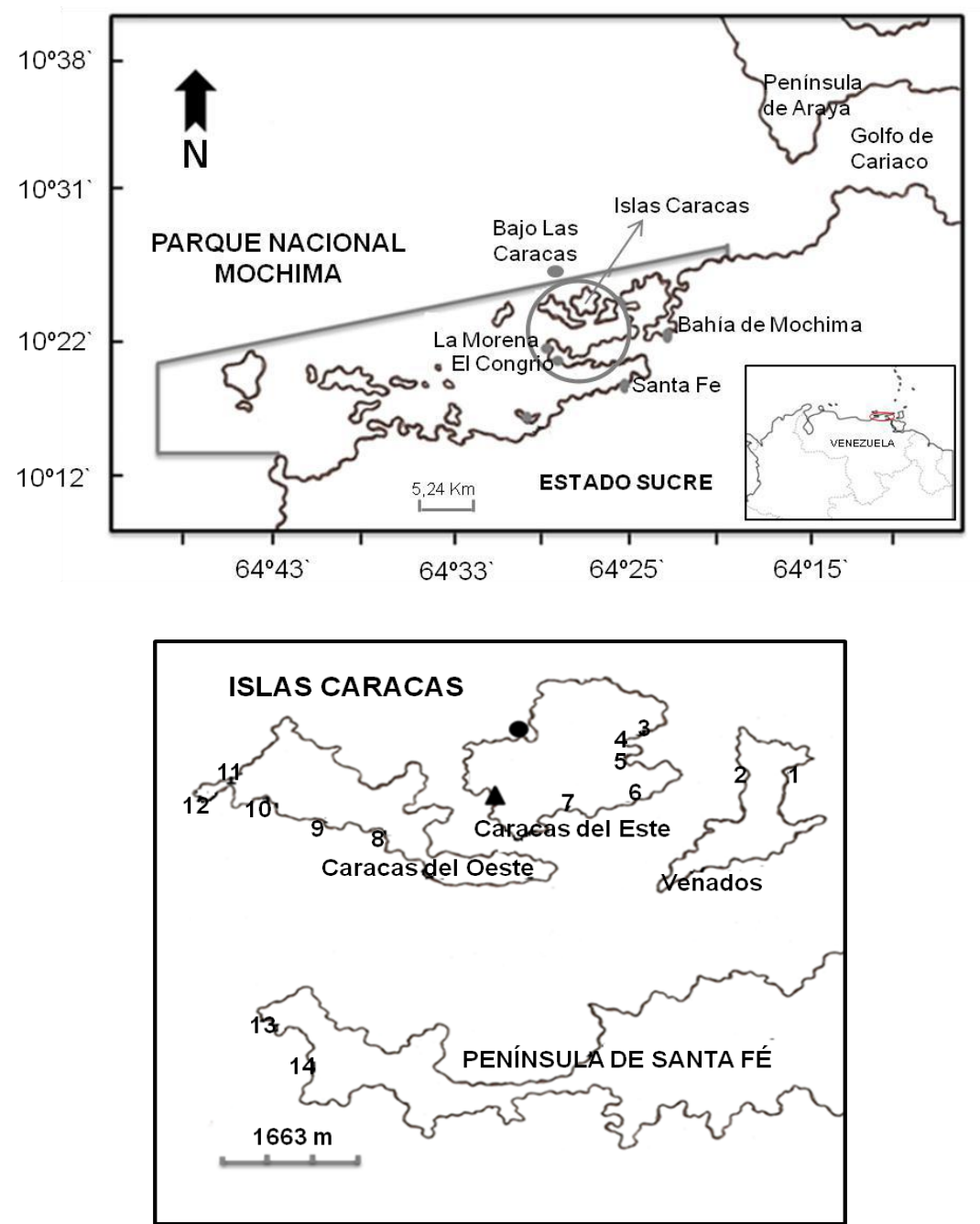

Figure 1. Geographical location of study area and sampling stations: Corocorero (1), Playa Piedra (2), La Anegada (3), El Mangle (4), Puerto Escondido de la Anegada (5), Don Jacinto (6), Morro Blanco (7), El Indio (8), Cruza las Patas (9), Playa May (10), Carenero (11), El Avance (12), La Morena (13) and El Congrio (14).

Figura 1. Ubicación geográfica del área de estudio y de las estaciones de muestreo: Corocorero (1), Playa Piedra (2), La Anegada (3), El Mangle (4), Puerto Escondido de la Anegada (5), Don Jacinto (6), Morro Blanco (7), El Indio (8), Cruza las Patas (9), Playa May (10), Carenero (11), El Avance (12), La Morena (13) y El Congrio (14).

to provide two specimens, which were preserved in ice until its identification in the laboratory.

\section{Statistical analysis}

A non-parametric test of Kruskal-Wallis was applied to verify if there were any differences regarding ethnoychtiological knowledge (number of species cited cuales fueron preservados en hielo hasta su identificación en el laboratorio.

\section{Análisis estadístico}

Se aplicó una prueba no paramétrica de KruskalWallis para verificar si existían diferencias en cuanto al conocimiento etnoictiológico (número de especies citadas 
as useful) amongst groups of ages of the studied population (10-17 years old; $18-30$ years old; $31-50$ years old and $>50$ years old). Since there were significant differences between age groups, a test $U$ from MannWhitney was made to make a comparison one by one between such groups. Also, $U$ tests of Mann-Whitney were made to determine if there were significant di- fferences in relation to the number of species cited as useful between sexes and localities (Islas Caracas and El Congrio-La Morena). It is important to mention that these nonparametric tests were applied because data did not fulfill the assumption of normality. The program used for such statistics was Statgraphics Plus 5.0.

\section{Results and Discussion}

\section{General socio-economic aspects}

In total, semi-structured questionnaires were applied to 214 people, from which most were found in the intervals of ages between 31-50 years old (32.24\%) and older than 50 years $(29.91 \%)$, followed by the group of $18-30$ years $(23.83 \%)$, being the group with ages of 10-17 years the one with least representation (14.02\%). Fariña et al., (2011), in a work made in the Peninsula of Paria, obtained similar results, with $32.85 \%$ of the studied population corresponding to people between 31 50 years old, followed by the group older than 50 years, between 18-30 years old and finally the youngest (10-17 years old). Likewise, Martinez (2004) found, in a study on the socio-economic aspects in downtown the locality of Santa Fe, nearby the State of Sucre, that the highest percentage of the population were in the ranges of age between 31-50 years (30.3\%); however, the group of people older than 50 years was the one with the least percentage $(9.9 \%)$.

Most of the studied people manifested a basic instruction level $(62.62 \%)$, followed by the group with a diversified level $(19.16 \%)$ and, in less percentage, graduate (9.81 $\%)$ and analphabet $(8.41 \%)$. These records coincide, in general terms, with the observed by Fariña et al., (2011) in fishery settlements of Paria, and with the observed by Martinez (2004) in Santa Fe. In this last place, 42.5 $\%$ of people surveyed indicated having a basic instruction level, followed by an average-diversified level (28.7 $\%)$, graduate $(25.0 \%)$ and only $3.7 \%$ appointed being analphabets. Santa $\mathrm{Fe}$ is a coast town that includes fishermen, but with an important number of productivity ac- cómo útiles) entre grupos de edades de la población estudiada (10-17 años; 18-30 años; 31-50 años y >50 años). Dado que se obtuvieron diferencias significativas entre los grupos de edades, se realizó una prueba $U$ de MannWhitney para hacer una comparación uno a uno entre tales grupos. También se efectuaron pruebas $U$ de Mann-Whitney para determinar si existían diferencias significativas en relación al número de especies citadas cómo útiles entre sexos y entre localidades (Islas Caracas y El Congrio-La Morena). Cabe destacar que se aplicaron estas pruebas no paramétricas debido a que los datos no cumplieron con el supuesto de normalidad. El programa empleado para la realización de tales estadísticos fue Statgraphics Plus 5.0.

\section{Resultados y Discusión}

\section{Aspectos socioeconómicos generales}

En total, se aplicaron cuestionarios semi estructurados a 214 personas de las cuales la mayoría se encontró en los intervalos de edades de 31-50 años (32.24 \%) y mayores de 50 años (29.91\%), seguidos por el grupo de 18-30 años (23.83\%), siendo el grupo con edades de 10-17 años el que tuvo menor representación (14.02\%). Fariña et al., (2011), en un trabajo realizado en la Península de Paria, señalaron resultados similares, con un $32.85 \%$ de la población estudiada correspondiendo a personas entre 31-50 años de edad, seguido por el grupo de mayores de 50 años, entre 18-30 años y por último los más jóvenes (10-17 años). De igual forma, Martínez (2004) en un estudio sobre aspectos socio-económicos del centro poblado de Santa Fe, una localidad cercana del estado Sucre, encontró que el mayor porcentaje de la población tenía edades comprendidas entre 31-50 años (30.3\%); sin embargo, el grupo de personas con edad mayor a 50 años fue el que denotó un menor porcentaje (9.9\%).

La mayoría de las personas estudiadas manifestaron tener un nivel de instrucción básico (62.62\%), seguido del grupo con un nivel diversificado (19.16\%) y, en menor porcentaje, superior $(9.81 \%)$ y analfabeta $(8.41 \%)$. Estos registros coinciden, en términos generales, con lo observado por Fariña et al., (2011) en asentamientos pesqueros de Paria y con lo observado por Martínez (2004) en Santa Fe. En esta última localidad, el $42.5 \%$ de los encuestados indicaron tener un nivel de instrucción básico, seguido por el nivel medio-diversificado (28.7\%), superior $(25.0 \%)$ y sólo un $3.7 \%$ señalaron ser analfabetas. Santa Fe es un pueblo costero que incluye trabajadores pesqueros pero también otro número importante de actividades productivas. Igualmente, presenta adecuadas vías de acceso y centros deatención 
tivities. In addition, in presents adequate access routes and medical attention centers (Martinez, 2004). In this sense, it is probable that the existing socioeconomic conditions, in the absence of services (including access to formal education) and isolation, in the studied communities in the Mochima National Park could be determined in higher dependence to fishery activity and in lower possibility of access to education, particularly the university. Also, the absence of study centers would contribute to the exodus of the youngest, from the studied localities to nearby centers, to access formal education.

From the total of the studied population, less than half $(36.73 \%)$ mentioned receiving weekly income; from these, the most represented group indicated income between 200-400 weekly bolivars (32.67\%), followed by the groups between $400-600$ bolivars (31.68 \%) and higher than 600 bolivars (30.69\%), while only a 4.95 $\%$ of people assured have weekly income lower than 200 bolivars. More than half of the population (54.18\%) practices fishing as the main activity, and from it they obtain their monetary resources. Being fishing an activity that depends on the environmental conditions and a dynamic resource in time and space, great part of the surveyed people could not give an amount on their weekly income, as they mentioned: "sometimes you fish a lot, sometimes you fish nothing".

Apart from fishing, the most cited main activity was housekeeper $(15.73 \%)$, students $(14.61 \%)$ and teachers (3.37\%); the rest of the population mentioned working as laborers or dedicate to several activities that include sewing work, carpenters, agriculture, upholstery, commerce, fiscal of goods and services, park keeper, tour guide and military officers. On the contrary, Martinez (2004) reported the occupation of housewife as the main activity in the town of Santa Fe, followed by commerce, agriculture, fishery, amongst others. Again, the importance of fishing as the main activity for the inhabitants of the Mochima National Park comes to light, where the isolation and limitation to transport would be the determining elements of this preference, apart from the existence of a fishing resource that, in many cases, is found abundantly and frequently at a very short distance from their homes.

\section{Fisheries aspects}

From the $65.63 \%$ inhabitants of the Mochima National Park that mentioned pracited fishing, only $38.89 \%$ médica (Martínez, 2004). En este sentido, es probable que las condiciones socioeconómicas, de ausencia de servicios (incluyendo el acceso a la educación formal) y de aislamiento, existentes en las comunidades estudiadas del Parque Nacional Mochima, pudieran estar determinando una mayor dependencia de la actividad pesquera y una menor posibilidad de acceso a la educación, particularmente a la universitaria. A su vez, la ausencia de centros de estudios estaría contribuyendo al éxodo de los más jóvenes desde las localidades estudiadas hacia centros cercanos, para acceder a la educaciónformal.

Del total de la población objeto de estudio, menos de la mitad (36.73\%) mencionó recibir ingresos semanales; de estos, el grupo más representado fue el que indicó obtener ingresos entre $200-400$ bolívares semanales (32.67\%), seguidos de los grupos entre 400-600 bolívares (31.68 \%) y mayor de 600 bolívares (30.69\%), mientras que únicamente un $4.95 \%$ de las personas aseguraron tener ingresos semanales menores a 200 bolívares. Más de la mitad de la población (54.18\%) practica la pesca como actividad principal $y$ es de ella de donde obtienen sus recursos monetarios. Al ser la pesca una actividad dependiente de las condiciones ambientales y de un recurso dinámico en el tiempo y en el espacio, gran parte de los encuestados no pudo dar una cifra de su ingreso semanal, ya que como ellos mencionaron: "a veces se pesca mucho y otras veces no se pesca nada".

Aparte de la pesca, la actividad principal más citada por los entrevistados fue el de amas de casa (15.73\%), estudiantes (14.61\%) y docentes (3.37\%); el resto de la población mencionó trabajar como obreros o dedicarse a actividades varias que incluyen trabajos de costura, carpintería, agricultura, tapicería, comercio, fiscal de bienes y servicios, guarda parques, guías turísticos y funcionarios militares. Por el contrario, Martínez (2004) reporta la ocupación de ama de casa como actividad principal en el centro poblado de Santa Fe, seguido por el grupo de comerciantes, agricultores, pescadores, entre otras ocupaciones. Nuevamente, resalta la importancia de la pesca como actividad principal para los pobladores del Parque Nacional Mochima, donde el aislamiento y las limitaciones para transportarse parecieran ser elementos determinantes en esta preferencia, además de la existencia de un recurso pesquero que, en muchos casos, se encuentra de manera abundante y frecuente, a poca distancia de sus hogares.

\section{Aspectos de pesquerías}

Del $65.63 \%$ de los pobladores del Parque Nacional Mochima, que mencionó practicar la pesca, sólo el 38.89 \% posee embarcación propia para dedicarse a la actividad, mientras que el resto de esas personas $(61.11 \%$ ) labora en faenas 
possesses own boat to perform such activity, while the rest of the people $(61.11 \%)$ works in fishes through the "parts" mechanism. According to this procedure, the full benefits of the capture are generally divided as follows: half of the profits correspond to net (or another fishing art), and from the other half, each engine receives two parts and the fisherman one part. This means, that in one boat with two engines and three people fishing, each fisherman only gets one tenth of the total profits.

The main arts of fishing used by the fishermen in the study zone are the fillet net type, purse seine (curtain type net), purse seines (shackle machine), string, longline and traps. Overall, the net and the shackle machine are fishing arts used by the most numerous groups of fishermen involving the highest number of vessels, specifically to capture species such as the horse mackerel, cojinoa, sardine, cachorreta and cataco, amongst others, which are usually captured in big amounts, with total biomasses that reach several tons. The other fishing arts mentioned are often used from only one boat where two, three, four or more fishermen fish, depending on the size of the vessel.

Time dedicated to the daily fishing often involves from 1 to $24 \mathrm{~h}$, with an average of $6 \mathrm{~h}$. Some fishermen mentioned they make fishing campaigns that can last from 15 to 30 days, and imply the displacement to other zones, such as the Isla La Tortuga, Las Isletas de Píritu (Anzoátegui State) and coasts from the state Miranda. The captured biomass is variable, and it shall depend on the fishing art, the target species and the fishing effort.

A total of 35 species as main fishing resources in the fishing zone (Table 1) were recorded. According to fishermen, the best season for fishing is from October to May, when captures are more abundant, but not all the before mentioned species are always obtained. The designated season includes an upwelling period that takes place in the zone from January to June, and that has as consequence the enriching of the waters by the income of nutrients, which generates an increase in the primary productivity, with positive effects on the different trophic marine wefts (Villarroel et al., 2004). Small pelagics such as sardine Sardinella aurita, and the chuparaco Decapterus punctatus, among others, would get close to the coast in great shoals to take advantage of the flowerings of plankton during the upwelling and, also, they would be determining high abundances from por el mecanismo de "partes". Según este procedimiento, los beneficios netos de la captura generalmente son divididos de la siguiente manera: la mitad de las ganancias le corresponden al chinchorro (u otro arte de pesca), de la otra mitad cada motor recibe dos partes y el pescador una parte. Es decir, que en una embarcación con dos motores y tres personas faenando, a cada pescador le viene tocando solo una décima parte de las ganancias totales.

Los principales artes de pesca empleados por los pescadores de la zona de estudio son la red tipo filete derivante, red de cerco (chinchorro tipo cortina), red de cerco con jareta (máquina de argolla), cordel, palangre y nasa. En las faenas de pesca se suelen involucrar desde una hasta quince embarcaciones. Por lo general, el chinchorro y la máquina de argollas son artes de pesca utilizadas por los grupos más numerosos de pescadores involucrando el mayor número de embarcaciones, específicamente para capturar especies como el jurel, la cojinoa, la sardina, la cachorreta y el cataco, entre otras, las cuales se suelen capturar en grandes cantidades, con biomasas totales que alcanzan varias toneladas. Los otros artes de pesca mencionados se suelen utilizar desde un solo bote en el cual faenan dos, tres, cuatro o más pescadores, dependiendo del tamaño de la embarcación.

El tiempo dedicado a la faena diaria de pesca suele involucrar desde $1 \mathrm{~h}$ hasta $24 \mathrm{~h}$, con un promedio de $6 \mathrm{~h}$. Algunos pescadores mencionaron realizar campañas de pesca que pueden durar de 15 a 30 días e implican el desplazamiento a otras zonas de pesca, por ejemplo, la Isla La Tortuga, Las Isletas de Píritu (estado Anzoátegui) y costas del estado Miranda. La biomasa capturada es variable, y va a depender del arte de pesca, de la especie objetivo y del esfuerzo de pesca.

Fueron registradas un total de 35 especies como principales recursos pesqueros en la zona (Tabla 1). De acuerdo a lo indicado por los pescadores, la mejor temporada para la pesca corresponde a los meses desde octubre a mayo, cuando las capturas son más abundantes, pero no siempre se obtienen todas las especies mencionadas. La temporada señalada incluye el periodo de surgencia continua que tiene lugar en la zona desde enero a junio y que trae como consecuencia un enriquecimiento de las aguas por el ingreso de nutrientes, lo cual genera un incremento en la productividad primaria, con efectos positivos sobre las distintas tramas tróficas marinas (Villarroel et al., 2004). Pequeños pelágicos como la sardina Sardinella aurita, y el chuparaco Decapterus punctatus, entre otros, se acercarían a la costa en grandes cardúmenes para aprovechar las floraciones de plancton durante la surgencia y, a su vez, estarían determinando altas abundancias de de- 
Table 1.

List of fishes reported as main fishing objectives in the Mochima National Park

Tabla 1.

Listado de peces reportados como objetivos principales de pesca en el Parque Nacional Mochima

\begin{tabular}{|c|c|c|c|}
\hline Taxon & Local Name & $\begin{array}{l}\text { Time of higher } \\
\text { abundance }\end{array}$ & Zone with abundance \\
\hline Seriola rivoliana & Atún medregal & Sep-dec/apr-jun & All MNP; La Picúa \\
\hline Euthynnus alletteratus & Cabaña pintada & Oct-may & El Congrio; Islas Caracas; La Picúa \\
\hline Sarda sarda & Cabaña blanca & Oct-may & All MNP; Anzoátegui \\
\hline Scomber colias & Cachorreta & Dec-jan & All MNP; Golfo de Cariaco; Golfo de Sta. Fe \\
\hline Selar crumenophtalmus & Cataco ojo gordo & Oct-dec & All MNP \\
\hline Priacanthus arenatus & Catalana & Dec & Anzoátegui; La Tortuga; Miranda \\
\hline Caranx crysos & Cojinoa & Oct-dec/apr-jul & All MNP; Anzoátegui; La Tortuga; Miranda \\
\hline Orthopristis ruber & Corocoro cabeza dura & Uniform & All MNP \\
\hline Mycteroperca acutirrostris & Cuna cucarachera & Uniform & La Picúa; MNP \\
\hline M. bonaci & Cuna guarei & Uniform & La Picúa; MNP \\
\hline M. cidi & Cuna garoupa & Uniform & La Picúa; MNP \\
\hline M. phenax & Cuna & Uniform & La Picúa; PNM \\
\hline Rhomboplites aurorubens & Cunaro & Uniform & Anzoátegui; Puerto Píritu; Miranda \\
\hline Coryphaena hippurus & Dorado & Uniform & Anzoátegui; La Tortuga; Miranda \\
\hline Caranx hippos & Jurel & Apr-jul & El Congrio; Islas Caracas; La Picúa, Anzoátegui \\
\hline Caranx latus & Jurel ojo gordo & Apr-jul & $\begin{array}{l}\text { El Congrio; Islas Caracas; La Picúa Anzoátegui; } \\
\text { La Tortuga; Miranda }\end{array}$ \\
\hline Selene setapinnis & Lamparosa & Sep-oct & El Congrio; all MNP \\
\hline Mugil liza & Lebranche & Feb-mar & Islas Caracas \\
\hline Mugil curema & Lisa & Mar & Islas Caracas \\
\hline Scarus coelestinus & Loro guacamayo azul & Uniform & Bajo Las Caracas; all MNP \\
\hline S. coeruleus & Loro martillo & Uniform & Bajo Las Caracas; all MNP \\
\hline S. guacamaya & Loro guacamayo & Uniform & Bajo Las Caracas; all MNP \\
\hline S. vetula & Loro & Uniform & Bajo Las Caracas; all MNP \\
\hline Sparisoma viride & Loro & Uniform & Bajo Las Caracas; all MNP \\
\hline Lutjanus analis & Pargo cebal & Oct-dec & Bajo Las Caracas; all MNP \\
\hline L. apodus & Pargo cotorro & Oct-dec & Bajo Las Caracas; all MNP \\
\hline L. cyanopterus & Pargo caballo & Oct-dec & Bajo Las Caracas; all MNP \\
\hline L. griseus & Pargo dientón & Oct-dec & Bajo Las Caracas; all MNP \\
\hline L. jocu & Pargo aguadera & Oct-dec & Bajo Las Caracas; all MNP \\
\hline L. mahogoni & Pargo anime & Oct-dec & Bajo Las Caracas; all MNP \\
\hline L. purpureus & Pargo rojo & Oct-dec & Islas Caracas \\
\hline L. synagris & Pargo guanapo & Oct-dec & Bajo Las Caracas; all MNP \\
\hline Sphyraena barracuda & Picúa & Uniform & All MNP \\
\hline Sardinella aurita & Sardina & Jan-mar & All MNP \\
\hline Trichiurus lepturus & Tajalí & Sep-dec & All MNP \\
\hline
\end{tabular}


predators of the highest size such as jureles, cojinoas and cabañas (Cervigón, 2005; Fariña and Méndez, 2009).

As it has been appointed, sardine is captured in higher amounts from January to March, but fishermen mention that it is present all year long, with less abundance. Fishing of this fish is one of the most important in the zone and in all east of the country, not only for its ecological meaning by working as feed to a great part of the species with fishing interest, but also as income of a relevant industrial activity. Annually, sardine captures are recorded in several tons, for example, by the year 2010 a total capture of $2.545 \mathrm{t}$ in the zone of Cumaná (INSOPESCA, 2011) was reported; great part of this resource was aimed to can and fish flour producing factories (CAIP, Alimentos Margarita, La Gaviota, etc.) using it as feedstock and another part was used as bait for fishing of other resources of commercial interest, which enhances the economic importance of the sardine.

Other fishing topics of great importance for the zone are the cojinoa ( $C$. crysos) and the jureles ( $C$. latus y $C$. hippos). Fishing of the latter requires a great amount of time, since fishermen tend to observe when great shoals get close to coast so that they can capture them with net. According to the informants, these fishes are captured in higher proportion on the months from April to July, along with one of the maximum of upwelling recorded in the zone (Febres, 1974; Okuda, 1978; Fariña and Méndez, 2009). Since these are piscivorous species fed mainly of sardine, their abundance period coincides with the one of such species.

Most of the fishing aim species by the inhabitants of the study area are captured throughout the Mochima National Park, specifically in places where artisanal fishing is allowed, among them: the surroundings of the Caracas Islands; Bajo Las Caracas, La Picúa, Golfo de Santa $\mathrm{Fe}$ and El Congrio. Other fishermen, especially from the localities of El Congrio and La Morena, mentioned fishing in zones of the states Anzoátegui (Isletas de Píritu mainly), Miranda and La Tortuga, since at certain times of the year, captures in this localities are of such abundance that they justify the transfer to these distant areas.

\section{Ethnoichthyological aspects}

24 species of fishes with medicinal properties were recorded (Table 2); in this group, both osseous and cartilaginous fishes are included, belonging to 14 families. predadores de mayor talla como jureles, cojinoas y cabañas (Cervigón, 2005; Fariña y Méndez, 2009).

Tal como se ha señalado, la sardina se captura en mayor cantidad los meses de enero a marzo pero los pescadores señalan que se encuentra presente todo el año, sólo que en menor abundancia. La pesca de este pez es una de las más importantes en la zona y en todo el oriente del país, no solo por su significado ecológico al servir de alimento a gran parte de las especies con interés pesquero, sino como sostén de una relevante actividad industrial. Anualmente, las capturas de sardina se registran en varias toneladas, por ejemplo, para el año 2010 fue reportada una captura total de $2.545 \mathrm{t}$ en la zona de Cumaná (INSOPESCA, 2011); gran parte de ese recurso fue dirigido a plantas productoras de enlatados y harina de pescado (CAIP, Alimentos Margarita, La Gaviota, etc.) empleándolo como materia prima y otra parte fue utilizada como carnada para la pesca de otros recursos de interés comercial, lo cual resalta la importancia económica de la sardina.

Otros rubros pesqueros de gran importancia para la zona son la cojinoa (C. crysos) y los jureles (C. latus y $C$. hippos). La pesca de estos últimos requiere gran dedicación de tiempo ya que los pescadores suelen observar cuando los grandes cardúmenes se acercan a la costa para luego poder capturarlos con chinchorro. Según los informantes, estos peces se capturan en mayor proporción los meses de abril a julio, coincidiendo con uno de los máximos de surgencia registrados en la zona (Febres, 1974; Okuda, 1978; Fariña y Méndez, 2009). Al ser estas especies piscívoras que se alimentan principalmente de sardina, su período de abundancia coincide con el de dicha especie.

La mayoría de las especies objetivo de pesca por los habitantes del área de estudio, son capturadas en todo el Parque Nacional Mochima, específicamente en los lugares donde está permitida la pesca artesanal, entre ellos: alrededores de las Islas Caracas; Bajo Las Caracas, La Picúa, Golfo de Santa Fe y El Congrio. Otros pescadores, especialmente los de las localidades de El Congrio y La Morena, mencionaron pescar en zonas de los estados Anzoátegui (Isletas de Píritu primordialmente), Miranda y en La Tortuga, debido a que, en ciertas épocas del año, las capturas en estas localidades son de tal abundancia que justifican un traslado aestas áreas distantes.

\section{Aspectos etnoictiológicos}

Se registraron 24 especies de peces con propiedades medicinales (Tabla 2); en este grupo están incluidos tanto peces óseos como cartilaginosos, pertenecientes a 14 familias. Los reportes de usos medicinales de los peces en Venezue- 
The reports on medicinal uses of fishes in Venezuela are scarce in literature, being Fariña et al., (2011), the only study published for this type of uses. Authors reported medicinal uses of 13 species of fishes in six localities of the Paria Peninsula, State Sucre. For the fishing communities from the Mochima National Park there is no record on the medicinal uses and other diverse uses to fishes, hence this study is a pioneer in the area.

Adeodato (1997) reports that the use of fishes in medicine has ancestral origins, existing records from the old era of infusions prepared by the romans from the poisonous device of the skate to heal toothache. Despite the fact that published papers on medicinal properties of fishes and ethnoicthyology in the country are scarce, in other countries, such as Brazil, studies that report medicinal uses of these animals are numerous. One of them is the study of Alves and Rosa (2006) who appointed the applications of 23 species of marine fishes in popular medicine from the inhabitants of the fishing communities in the northeast of Brazil. By comparing the uses recorded by these authors, and those indicated in this study, the coincidence in which great part of the cited species are used to cure asthma and other breathing diseases can be observed.

Most of the fishes, or some of their parts, are used as anti-asthmatic, antitussives, antiseptics and tetanus. Other medicinal properties of cited taxa were used as laxative to treat ear pain, avoid hair falling, against osteoporosis, among others (Table 2). In this study, five species of fishes with anti-asthmatic properties were reported: seahorse, dogfish, chucho, stingray and remora. The use of animals, their parts or derived products, such as antiasthmatic, was previously appointed by Alves and Rosa (2006), for fishing communities in the northeast of Brazil. The authors mentioned that this is a condition with a wide variety of animal products to be treated, amongst which, some fish species are included. Costa-Neto (1999) recorded that remedies based in animals are frequently used to treat respiratory diseases; in addition, Almeida and Albuquerque (2002) cited that one of the categories of most treated diseases with medicines based in animals are those belonging to the respiratory system. For communities in the Paria Peninsula, also in the state of Sucre, Fariña et al., (2011) cited among the main medicinal uses of fishes and their derivatives (and other marine organisms), their usage as anti-asthmatic, antitussive, la son escasos en la literatura, siendo el de Fariña et al., (2011), el único trabajo que ha publicado este tipo usos. Los autores reportaron usos medicinales de 13 especies de peces en seis localidades de la Península de Paria, estado Sucre. Para las comunidades pesqueras del Parque Nacional Mochima no se tiene ningún registro escrito sobre los usos medicinales y otros usos diversos dados a los peces, por lo que este estudio resulta pionero en el área.

Adeodato (1997) reporta que el empleo de peces en la medicina tiene orígenes ancestrales, existiendo registros desde la antigüedad de infusiones preparadas por los romanos a partir del aparato venenoso de la raya, para curar el dolor de muelas. A pesar de que en el país son escasos los trabajos publicados referentes a las propiedades medicinales de los peces y de etnoictiología en general, en otros países como Brasil, abundan estudios que reportan usos medicinales de este grupo de animales. Uno de esos estudios es el de Alves y Rosa (2006) quienes señalaron las aplicaciones de 23 especies de peces marinos en la medicina popular por parte de los habitantes de comunidades pesqueras en el noreste de Brasil. Al comparar los usos registrados por estos autores y los indicados en el presente estudio, se observa la coincidencia en que gran parte de las especies citadas se emplean para curar el asma y otras afecciones respiratorias.

La mayoría de los peces, o de sus partes, son empleados como antiasmáticos, antitusígenos, antisépticos y antitetánicos. Otras propiedades medicinales de los taxones citados fueron como laxante, para tratar el dolor de oídos, para evitar la caída del cabello, contra la osteoporosis, entre otras (Tabla 2). En este estudio se reportaron cinco especies de peces con propiedades antiasmáticas: caballito de mar, cazón, chucho, raya y rémora. El uso de animales, sus partes o productos derivados de estos, como antiasmáticos, fue señalado anteriormente por Alves y Rosa (2006), para comunidades pesqueras en el noreste de Brasil. Los autores mencionados acotaron que esta es una condición con una amplia variedad de productos animales para ser tratada, dentro de los cuales se incluyen algunas especies de peces. Costa-Neto (1999) registró que remedios basados en animales frecuentemente se emplean para tratar enfermedades respiratorias; de igual manera Almeida y Albuquerque (2002) citaron que una de las categorías de enfermedades más tratadas con medicinas a base animales son aquellas pertenecientes al sistema respiratorio. Para comunidades de la Península de Paria, también en el estado Sucre, Fariña et al., (2011) citaron entre los principales usos medicinales de los peces o sus derivados 
Table 2.

List of fishes with medicinal properties recorded by the inhabitants of the studied localities in the Mochima National Park

Tabla 2.

Listado de peces con propiedades medicinales registrados por los pobladores de las localidades estudiadas en el Parque Nacional Mochima

\begin{tabular}{|c|c|c|c|c|c|}
\hline Taxon & Local name & PCU & Preparation & AP & $\begin{array}{l}\text { Properties } \\
\text { or illness it } \\
\text { treats }\end{array}$ \\
\hline Gadus morhua & Bacalao & $\mathrm{H}$ & Commercially obtained oil & $\mathrm{I}$ & ATU \\
\hline Rachycentron canadum & Bacallao & GV & Placed in sun so it distills oil & I & ATU \\
\hline Hippocampus erectus & Seahorse & CE & Boiled in water & $\mathrm{T}$ & AN \\
\hline H. erectus & Seahorse & CE & $\begin{array}{l}\text { Dry under sun, introduced in a bottle of } \\
\text { rum with some plants. }\end{array}$ & $\mathrm{T}$ & $\begin{array}{c}\text { AN } \\
\text { (bone pain) }\end{array}$ \\
\hline H. erectus & Seahorse & CE & Dry under sun & $\mathrm{T}$ & DIU \\
\hline H. erectus & Seahorse & CE & $\begin{array}{l}\text { Dry under sun, smashed and con- } \\
\text { sumed as tea. }\end{array}$ & I & AAS \\
\hline H. erectus & Seahorse & CE & $\begin{array}{l}\text { Dry under sun, place in water glass } \\
\text { and drink in fasting. }\end{array}$ & 1 & AAS \\
\hline Selar crumenophtalmus & Cataco & CE & Consumed grilled or fried & 1 & COL \\
\hline Priacanthus arenatus & Catalana & CE & Consumed grilled or fried & I & COL \\
\hline Carcharhinidae, Lamnidae & Cazón & $\mathrm{H}$ & Placed in sun so it distills oil & I & AAS \\
\hline Carcharhinidae, Lamnidae & Cazón & C & Boiled in water & I & AAS \\
\hline Aetobatus narinari & Chucho & $\mathrm{L}$ & $\begin{array}{l}\text { Dry under sun, smashed and con- } \\
\text { sumed as tea. }\end{array}$ & I & AAS \\
\hline Mycteroperca acutirrostris & $\begin{array}{l}\text { Cuna cucara- } \\
\text { chera }\end{array}$ & GV & Placed in sun so it distills oil & $\mathrm{T}$ & ATE, ASE \\
\hline M. bonaci & Cuna guarei & GV & Placed in sun so it distills oil & $\mathrm{T}$ & ATE, ASE \\
\hline M. cidi & Cuna garoupa & GV & Placed in sun so it distills oil & $\mathrm{T}$ & ATE, ASE \\
\hline M. phenax & Cuna & GV & Placed in sun so it distills oil & $\mathrm{T}$ & ATE, ASE \\
\hline Lutjanus analis & Pargo cebal & GV & Placed in sun so it distills oil & $\mathrm{T}$ & ATE, ASE \\
\hline L. apodus & Pargo cotorro & GV & Placed in sun so it distills oil & $\mathrm{T}$ & ATE, ASE \\
\hline L. cyanopterus & Pargo caballo & GV & Placed in sun so it distills oil & $\mathrm{T}$ & ATE, ASE \\
\hline L. griseus & Pargo dientón & GV & Placed in sun so it distills oil & $\mathrm{T}$ & ATE, ASE \\
\hline L. jocu & $\begin{array}{l}\text { Pargo agua- } \\
\text { dera }\end{array}$ & GV & Placed in sun so it distills oil & $\mathrm{T}$ & ATE, ASE \\
\hline L. mahogoni & Pargo anime & GV & Placed in sun so it distills oil & $\mathrm{T}$ & ATE, ASE \\
\hline L. synagris & Pargo guanapo & GV & Placed in sun so it distills oil & $\mathrm{T}$ & ATE, ASE \\
\hline Dasyatis americana & Stingrey & $\mathrm{H}$ & Placed in sun so it distills oil & $\mathrm{T}$ & ATE, ASE \\
\hline D. americana & Stingrey & $\mathrm{H}$ & Placed in sun so it distills oil & $\mathrm{I}$ & AAS, ATU \\
\hline D. americana & Stingrey & $\mathrm{H}$ & $\begin{array}{l}\text { Placed in sun so it distills oil, then it is } \\
\text { linked with red onion. }\end{array}$ & l & AAS \\
\hline D. americana & Stingrey & $\mathrm{H}$ & Placed in sun so it distills oil & $\mathrm{T}$ & ART \\
\hline D. americana & Stingrey & $\mathrm{C}$ & Boiled in water & I & CCAB \\
\hline
\end{tabular}




\begin{tabular}{|l|l|c|l|l|l|}
\hline D. americana & Stingrey & $\mathrm{H}$ & Placed in sun so it distills oil & $\mathrm{I}$ & Laxative \\
\hline D. guttata & Stingrey & $\mathrm{H}$ & Placed in sun so it distills oil & $\mathrm{T}$ & ATE, ASE \\
\hline D. guttata & Stingrey & $\mathrm{H}$ & Placed in sun so it distills oil & I & AAS, ATU \\
\hline D. guttata & Stingrey & $\mathrm{H}$ & $\begin{array}{l}\text { Placed in sun so it distills oil, then it is } \\
\text { linked with red onion. }\end{array}$ & $\mathrm{I}$ & AAS \\
\hline D. guttata & Stingrey & $\mathrm{H}$ & Placed in sun so it distills oil & $\mathrm{T}$ & ART \\
\hline D. guttata & Stingrey & $\mathrm{C}$ & Boiled in water & $\mathrm{I}$ & CCAB \\
\hline D. guttata & Stingrey & $\mathrm{H}$ & Placed in sun so it distills oil & I & Laxante \\
\hline Remora remora & Rémora & $\mathrm{CE}$ & $\begin{array}{l}\text { Dry under sun, smashed and con- } \\
\text { sumed as tea. }\end{array}$ & $\mathrm{I}$ & AAS \\
\hline Centropomus ensiferus & Robalo & GV & Placed in sun so it distills oil & T & ATE, ASE \\
\hline C. undecimalis & Robalo & GV & Placed in sun so it distills oil & T & ATE, ASE \\
\hline Sardinella aurita & Sardina & CE & Soup & I & HEMO \\
\hline S. aurita & Sardina & CE & Dry under sun, drink with milk & I & OST \\
\hline
\end{tabular}

AAS: anti-asthmatic, AN: analgesic, AP: application, ASE: antiseptic, ATE: anti-tetanus, ATU: antitussive, C: cartilage, CCAB: hair loss CE: full body, COL: regularize cholesterol, DIU: diuretic, GV: visceral fat, H: liver, HEMO: raises hemoglobin, I: ingested, L: tongue, OST: osteoporosis, T: topic.

AAS: antiasmático, AN: analgésico, AP: aplicación, ASE: antiséptico, ATE: antitetánico, ATU: antitusígeno, C: cartílago, CCAB: caída del cabello, CE: cuerpo entero COL: regulariza colesterol, DIU: diurético, GV: grasa visceral, H: hígado, HEMO: sube la hemoglobina, I: ingerida, L: lengua, OST: osteoporosis, T: tópico.

antiseptic, anti-inflammatories, energizing, tetanus, healing, antiepileptic, analgesic, and others.

The properties of the stingray (Dasyatis spp.) as antiasthmatic had already been mentioned by authors as Alves and Rosa (2006), by reporting the animal uses as remedies in fishing communities in the northeast of Brazi; nevertheless, the way to apply the remedy was not the same as the one mentioned by the people inhabiting the study area in this work, since they use liver oil as syrup, while according to people from Northeast Brazil, a tea based in the fish teeth must be ingested. Fariña et al., (2011) reported the use of this species as antiasthma in localities of Paria, with the same application form than the one cited in this study. Alves and Rosa (2006) also appoint the use of stingray (Dasyatis spp.) liver oil as antiseptic, indicated to treat injuries made by the same fish, coinciding with that appointed by the people of the sector Islas Caracas-La Morena, since according to them, stingray oil is used as antiseptic and anti-tetanus to treat any injury.

In the case of the seahorse, it is used to relieve ear pain, and as antiasthma and diuretic. This is one of the (y otros organismos marinos) su empleo como antiasmático, antitusígeno, antiséptico, antiinflamatorio, energizante, antitetánico, cicatrizante, antiepiléptico, analgésico, entre otros. Las propiedades de la raya (Dasyatis spp.) como antiasmático ya han sido citadas por autores como Alves y Rosa (2006), al reportar los usos de animales como remedios en comunidades pesqueras del noreste de Brasil; sin embargo, la forma de aplicar el remedio no fue la misma citada por los pobladores del área de estudio en el presente trabajo, ya que estos emplean el aceite del hígado como jarabe, mientras que según los pobladores del noreste de Brasil se debe ingerir un té hecho a base de los dientes del pez. Cabe destacar que Fariña et al., (2011) reportaron el uso de esta especie como antiasmático en localidades de Paria, con la misma forma de aplicación que la citada en el presente estudio. Alves y Rosa (2006) también señalan el uso del aceite del hígado de la raya (Dasyatis spp.) como antiséptico, indicado para tratar heridas hechas por el mismo pez, coincidiendo con lo señalado por los pobladores del sector Islas Caracas-La Morena ya que de acuerdo con ellos, el aceite de la raya es empleado como antiséptico y antitetánico para tratar cualquier herida.

En el caso del caballito de mar, este es empleado para aliviar el dolor de oídos, como antiasmático y diurético. Esta es una de 
mostly used species in traditional medicine of Brazil (Alves and Rosa, 2006), enhanced by its property of antiasthma and being ingested in the same form as mentioned in this study (as tea). These authors reported the use of some parts of chucho as antiasthma, agreeing with the findings in the sector Islas Caracas-La Morena. Other species used as antiasthma in the study zone are dogfish and remora with antiseptic and antitetanic properties, also snapper, cunas and sea bass. On the other hand, it was mentioned that sardine is used to treat the osteoporosis and regulate hemoglobin levels, while the catalana and the cataco regulate cholesterol levels (Table 2). One good part of the species with medicinal used before mentioned constitute new contributions that had not been appointed in previous works. Such is the case of the remora as antiasthma, sardine to treat osteoporosis, among others.

In contrast, the evaluated population mentioned that fishes also tend to be used as ornaments, devices, personal defense weapons, poison, prophylactic, aphrodisiac and amulets. In total, 28 species of fishes were reported with diverse uses and most of these were appointed as ornamental (Table 3).

Most of the diverse uses cited in this study (75\%) constitute new records for Venezuela; however, by comparing these results with those from Fariña et al., (2011) in Paria, the coincidence in certain uses can be observed, such as: poisonous properties of tamboril (Sphoeroides spengleri), used to poison vermin; the ornamental use of Shark's jaw (Carcharhinidae, Lamnidae); the use as custom jewelry from the scales of sabalo (Megalops atlanticus); same as the use of the sting of stingrey (Dasyatis spp.) as prophylactic and its tail as personal defense weapon.

Worldwide, results in this work agree with reports about some uses, such as the venom properties of tamboril, which is recorded in the scientific literature for several species of the Tetraodontidae family, which have tetrodotoxin in their guts, a potent toxin that affects the nervous transmission and muscular contraction, causing death to whom ingests it (Field-Cortazares et al., 2009). These authors appoint that in China it is common to dry the puffer fish and use it as a lamp, use that is also cited by the local people of the studied communities in the Mochima National Park. On the other hand, the use of fishes' otoliths has also been recorded as amulet, specifically of meagre (Argyrosomus regius); according to Lopez (2011), in a study made in the Cadiz Bay las especies de peces más utilizadas en la medicina tradicional de Brasil (Alves y Rosa, 2006), destacándose su propiedad como antiasmático e ingiriéndose de la misma forma como se hace mención en este estudio (como té). Estos mismos autores reportaron el empleo de partes del chucho como antiasmático coincidiendo con lo hallado en el sector Islas Caracas-La Morena. Otras especies empleadas como antiasmático en la zona de estudio son el cazón y la rémora con propiedades antisépticas y antitetánicas, también destacan los pargos, las cunas y el robalo. Por otra parte, se hizo mención que la sardina es usada para tratar la osteoporosis y regularizar los niveles de hemoglobina, mientras que la catalana y el cataco regulan los niveles de colesterol (Tabla 2). Una buena parte de las especies con usos medicinales citadas anteriormente constituyen nuevos aportes que no habían sido señalados en trabajos previos. Tal es el caso del uso de la rémora como antiasmático, la sardina para tratar la osteoporosis, entreotros.

Por otro lado, la población evaluada mencionó que los peces también suelen usarse como ornamentos, utensilios, armas de defensa personal, veneno, profiláctico, afrodisiaco y amuleto. En total, fueron reportadas 28 especies de peces con usos diversos y la mayoría de estos fueron nombrados como ornamentales (Tabla 3 ).

La mayoría de los usos diversos citados en este estudio (75\%) constituyen nuevos registros para Venezuela; sin embargo, al comparar estos resultados con los de Fariña et al., (2011) en Paria, se observa la coincidencia en ciertos usos, como son: la propiedad venenosa del tamboril (Sphoeroides spengleri), empleado para envenenar alimañas; el uso ornamental de la mandíbula de tiburón (Carcharhinidae, Lamnidae); el empleo como material para bisutería de las escamas del sábalo (Megalops atlanticus); al igual que el uso del aguijón de la raya (Dasyatis spp.) como profiláctico y su cola como arma de defensa personal.

En el ámbito mundial, los resultados de este trabajo concuerdan con reportes acerca de algunos usos, como es el caso de la propiedad venenosa del tamboril, la cual se encuentra registrada en la literatura científica para varias especies de la familia Tetraodontidae, que tienen tetrodotoxina en sus vísceras, siendo esta una potente toxina que afecta la transmisión nerviosa y la contracción muscular, ocasionando muchas veces la muerte a quien la ingiera (Field-Cortazares et al., 2009). Estos mismos autores señalan que en China se suele secar el pez globo erizo y utilizarlo como lámpara siendo tal uso citado también por los pobladores de las comunidades estudiadas en el Parque Nacional Mochima. Por otra parte, también ha sido registrado el uso de otolitos de peces cómo amuleto, específicamente de la curvina (Argyrosomus regius); de acuerdo con López (2011), 
Table 3.

List of fishes with diverse uses recorded by the people living in the studied localities in the Mochima National Park

Tabla 3.

Listado de peces con usos diversos registrados por los pobladores de las localidades estudiadas en el Parque Nacional Mochima

\begin{tabular}{|c|c|c|c|c|}
\hline Taxon & Local Name & PCU & Use & Description \\
\hline Hippocampus erectus & Seahorse & CE & $\mathrm{O}$ & Dried at sun and used as ornament \\
\hline Balistes vetula & Cachúa & CE & $\mathrm{O}$ & Dried at sun and used as ornament \\
\hline Coryphaena hippurus & Dorado & CE & $\mathrm{O}$ & Dried at sun and used as ornament \\
\hline Dactylopterus volitans & Gallineta & CE & $\mathrm{O}$ & Dried at sun and used as ornament \\
\hline Chilomycteru santillarum & Globo erizo & CE & $\mathrm{O}$ & Dried at sun and used as ornament (lamp) \\
\hline Diodon holocanthus & Globo erizo & CE & $\mathrm{O}$ & Dried at sun and used as ornament (lamp) \\
\hline D. hystrix & Globo erizo & CE & $\mathrm{O}$ & Dried at sun and used as ornament (lamp) \\
\hline Chaetodon capistratus & Isabelita & CE & $\mathrm{O}$ & Dried at sun and used as ornament \\
\hline C. ocellatus & Isabelita & CE & $\mathrm{O}$ & Dried at sun and used as ornament \\
\hline C. sedentarius & Isabelita & CE & $\mathrm{O}$ & Dried at sun and used as ornament \\
\hline C. striatus & Isabelita & CE & $\mathrm{O}$ & Dried at sun and used as ornament \\
\hline Caranx hippos & Jurel & $A C$ & $\mathrm{O}$ & Dried at sun and used as ornament \\
\hline Scarus coelestinus & $\begin{array}{l}\text { Loro guacama- } \\
\text { yo azul }\end{array}$ & $\mathrm{E}$ & $\mathrm{O}$ & $\begin{array}{l}\text { Secas, se hacen zarcillos, collares y otros acceso- } \\
\text { rios, o adornos para el hogar }\end{array}$ \\
\hline S. coeruleus & Loro martillo & $\mathrm{E}$ & $\mathrm{O}$ & $\begin{array}{l}\text { Secas, se hacen zarcillos, collares y otros acceso- } \\
\text { rios, o adornos para el hogar }\end{array}$ \\
\hline S. guacamaya & Loro guacamayo & $E$ & $\mathrm{O}$ & $\begin{array}{l}\text { Dried, earrings, necklaces and other accesories or } \\
\text { home ornaments are made }\end{array}$ \\
\hline S. vetula & Loro & $\mathrm{E}$ & $\mathrm{O}$ & $\begin{array}{l}\text { Dried, earrings, necklaces and other accessories or } \\
\text { home ornaments are made }\end{array}$ \\
\hline Sparisoma viride & Loro & $E$ & $\mathrm{O}$ & $\begin{array}{l}\text { Dried, earrings, necklaces and other accessories or } \\
\text { home ornaments are made }\end{array}$ \\
\hline Hemiramphus brasiliensis & $\begin{array}{l}\text { Marao (cabeza } \\
\text { de fosforo) }\end{array}$ & CE & AF & It is cooked and ingested \\
\hline Ogcocephalus nasutus & Murciélago & CE & $\mathrm{O}$ & Dried at sun and used as ornament \\
\hline Istiophorus albicans & Palagar & HUE & A & Hanging in a necklace is used as amulet for good luck \\
\hline Umbrina coroides & Petota & Ot & $A$ & Hanging in a necklace is used as amulet for good luck \\
\hline D. americana & Stingrey & $\mathrm{Ag}$ & Pro & $\begin{array}{l}\text { Dried and clean it is used to remove nits and lice } \\
\text { from hair }\end{array}$ \\
\hline D. americana & Stingrey & $A C$ & $\mathrm{D}$ & Dried at sun and used as defense weapon (whip) \\
\hline D. americana & Stingrey & $A C$ & $\mathrm{O}$ & Dried at sun and used as defense weapon \\
\hline D. americana & Stingrey & Len & A & Hanging in a necklace is used as amulet for good luck \\
\hline D. guttata & Stingrey & $\mathrm{Ag}$ & Pro & $\begin{array}{l}\text { Dried and clean it is used to remove nits and lice } \\
\text { from hair }\end{array}$ \\
\hline D. guttata & Stingrey & $A C$ & $\mathrm{O}$ & Dried at sun and used as ornament \\
\hline
\end{tabular}




\begin{tabular}{|c|c|c|c|c|}
\hline D. guttata & Stingrey & Len & $A$ & Hanging in a necklace is used as amulet for good luck \\
\hline Micropogonias furnieri & Roncador & Ot & A & Hanging in a necklace is used as amulet for good luck. \\
\hline Megalops atlanticus & Sábalo & $E$ & $\mathrm{O}$ & $\begin{array}{l}\text { Dried, earrings, necklaces and other accessories or } \\
\text { home ornaments are made }\end{array}$ \\
\hline Scorpaena plumieri & Sapo charneta & CE & $\mathrm{AF}$ & Se cocina y se ingiere \\
\hline Scorpaena plumieri & Sapo charneta & CE & $\mathrm{O}$ & Dried at sun and used as ornament \\
\hline Sphoeroides spengleri & Tamboril & $\mathrm{H}$ & V & It is used raw as poison against vermin \\
\hline Carcharhinidae, Lamnidae & Shark & $\begin{array}{c}\mathrm{M} \\
\text { (dien- } \\
\text { tes) }\end{array}$ & A & $\begin{array}{l}\text { Hanging in a necklace is used as amulet for } \\
\text { good luck }\end{array}$ \\
\hline Carcharhinidae, Lamnidae & Shark & M & $\mathrm{O}$ & $\begin{array}{l}\text { Separated from head, dry and clean, it is used as } \\
\text { ornament }\end{array}$ \\
\hline Carcharhinidae, Lamnidae & Shark & Ale & $U$ & It is processed and used as stitch. \\
\hline Acanthostracion quadricornis & Torito & CE & O & Dried at sun and used as ornament \\
\hline Laptophris bicaudalis & Torito & CE & $\mathrm{O}$ & Dried at sun and used as ornament \\
\hline
\end{tabular}

A: amulet; AC: caudal fin; AF: aphrodisiac; Ag: sting; Ale: flap; CE: full body; D: personal defense; E: scales; H: liver; HUE: bone; Len: language; M: jaw; O: ornamental; Ot: otolith; PCU: body part used, Pro: prophylactic; U: utensil; V: venom.

A: amuleto; AC: aleta caudal; AF: afrodisiaco; Ag: aguijón; Ale: aleta; CE: cuerpo entero; D: defensa personal; E: escamas; $\mathrm{H}$ : hígado; HUE: hueso; Len: lengua; M: mandíbula; O: ornamental; Ot: otolito; PCU: parte del cuerpo utilizada, Pro: profiláctico; U: utensilio; V: veneno.

(Spain) "the carrier of the otolith considers the amulet as a talisman that has properties to expel evil and spells". In the case of the people from Islas Caracas-La Morena, they appoint the use of these structures (otoliths) as talisman but from different species of the family Sciaenidae, Umbrina coroides, better known as petota.

\section{Statistical analysis}

Regarding sex, no significant differences were found regarding ethnoichthyological knowledge ( $p>0.05 ; \mathrm{W}=8145.5 ; \mathrm{P}=0.997354)$, meaning that both men and women reported similar numbers of species of useful fishes. Fariña et al., (2011) appoint that in six localities from the Paria Peninsula no significant differences between genres regarding ethnobiological marine knowledge were found. Likewise, in ethnobotanical studies, Freites (2004) and Marcano (2003) found no significant differences between sexes in relation to the number of plants cited as useful. Such situation could be the reflection of a similar interaction between men and women with the surrounding biota. en un estudio realizado en la Bahía de Cádiz (España) "el portador del otolito considera el amuleto como un talismán que posee propiedades para ahuyentar el mal y los maleficios". En el caso de los pobladores del sector Islas Caracas-La Morena, estos señalan el empleo de estas estructuras (otolitos) como talismán pero de otra especie de la familia Sciaenidae, Umbrina coroides, conocida comúnmente como petota.

\section{Análisis estadísticos}

En cuanto al sexo, no se encontraron diferencias significativas respecto al conocimiento etnoictiológico $(p>0.05 ; W=8145.5 ; P=0.997354)$, es decir, que tanto hombres como mujeres reportaron números similares de especies de peces útiles. Fariña et al., (2011) en seis localidades de la Península de Paria, señalan que tampoco se dieron diferencias estadísticamente significativas entre sexos respecto conocimiento etnobiológico marino. De igual forma, en estudios etnobotánicos, Freites (2004) y Marcano (2003) no hallaron diferencias significativas entre sexos en relación al número de plantas citadas cómo útiles. Tal situación pudiera estar reflejando una interacción similar entre hombres y mujeres con la biota que los rodea. 
Significant differences between groups of ages of the studied population were found $(p<0.05 ; \mathrm{H}=26.1919$; $\mathrm{P}=0.00000869441$ ) in respect to ethnoichthyological knowledge. When performing the comparison one by one to the age groups, significant differences were observed in relation to the number of species cited as useful between groups 1-2 (10-17 years and 18-30 years old), 1-3 (10-17 and 31-50 years old), 1-4 (10-17 years and $>50$ years old), $2-4$ ( $18-30$ years and $>50$ years old) and 3-4 (31-50 years and $>50$ years old) (Table IV).

Groups of ages from 10-17 years and 18-30 years old were the ones that presented less ethnoichthyological knowledge, while the other two groups cited the highest quantity of species of useful fishes. These results reflect a similar tendency to the one reported by Fariña et al., (2011) for the Paria Peninsula, who found high significant differences in respect to ethnobiological marine knowledge, appointing that the group of the young gave less number of species cited as useful and the olders named the highest useful species. This tendency of results has also been observed by other authors in ethnobotanics studies, who observed that possibly, the lack or low knowledge was due to the short age and less experience or to the fact that knowledge was not being effectively transmitted from generation to generation (Marcano, 2003; Freites, 2004).

Nevertheless, Velasquez (2003) in the Campoma community, Sucre State, appointed that no significant differences had been found (regarding ethnoknowledge) between the same groups of ages established in this
Se encontraron diferencias significativas entre los grupos de edades de la población de estudio ( $p<0.05 ; \mathrm{H}=26.1919$; $\mathrm{P}=0.00000869441$ ), respecto al conocimiento etnoictiológico. Al realizar la comparación uno a uno de los grupos de edades, se observaron diferencias significativas en cuando al número de especies citadas cómo útiles entre los grupos 1-2 (10-17 años y 18-30 años), 1-3 (10-17 años y 31-50 años), 1-4 (10-17 años $y>50$ años), 2-4 (18-30 años $y>50$ años) y 3-4 (31-50 años y >50años) (Tabla IV).

Los grupos de edades de 10-17 años y de 18-30 años fueron los que denotaron menor conocimiento etnoictiológico, mientras que los dos grupos restantes citaron la mayor cantidad de especies de peces útiles. Estos resultados reflejan una tendencia similar a la reportada por Fariña et al., (2011) para la Península de Paria, quienes encontraron diferencias altamente significativas respecto al conocimiento etnobiológico marino, señalándose que el grupo de los jóvenes aportaron menor número de especies citadas cómo útiles y los de mayor edad nombraron la mayor cantidad de especies útiles. Esta tendencia de los resultados también ha sido observada por otros autores en estudios de etnobotánica, quienes señalaron que, posiblemente, el poco o bajo conocimiento se deba a la corta edad y menor experiencia o bien a que el conocimiento no se esté transmitiendo efectivamente de generación en generación (Marcano, 2003; Freites, 2004).

No obstante, Velásquez (2003) en la comunidad de Campoma, estado Sucre, señaló no haber encontrado diferencias significativas (respecto al etnoconocimiento) entre los mismos grupos de edades establecidos en este trabajo; lo cual pudiera reflejar que más que el hecho de ser muy jóve-

Table IV.

Results of $U$ tests from Mann-Whitney (Wilcoxon) to prove paired differences between groups of ages in relation with the number of cited species as useful. Tabla IV.

Resultados de las pruebas U de Mann-Whitney (Wilcoxon), para comprobar diferencias pareadas entre grupos de edades con relación al número de especies citadas como útiles.

\begin{tabular}{ccc}
\hline Contrastes groups of ages & Statistician W & Value P \\
\hline $1-2$ & 1548.5 & ${ }^{*} 0.0160008$ \\
$1-3$ & 2274.5 & ${ }^{*} 0.000187621$ \\
$1-4$ & 1235.0 & ${ }^{*} 0.0001349$ \\
$2-3$ & 3813.5 & 0.108838 \\
$2-4$ & 3490.5 & ${ }^{*} 0.00182919$ \\
$3-4$ & 4230.5 & $\mathrm{P} 0.0357476$ \\
\hline
\end{tabular}


work; the latter could reflect that beyond the fact that the inhabitants of this semi-isolated communities of the Mochima National Park are young to have a wide knowledge of the use of fishes, it could be the reflection on the deficiencies in the knowledge transmission from generation to generation. Hence, the importance of this work in the maintenance of popular knowledge on fish, a cultural value significantly relevant in the zone, is confirmed.

In relation to the comparison of the ethnoichthyological knowledge regarding localities, all settlements from Las Caracas were grouped and compared to those form El Congrio-La Morena. Results indicate the existence of significant differences between both sectors $(p<0.05$ $W=3172.0 ; P=0.0059707$ ), despite the fact that in both there is lack or inexistence of medical assistance centers.

People from Congrio-La Morena showed more knowledge on the uses of fishes than the inhabitants of the Islas Caracas. This results a bit contradictory, since it is generally expected that localities farther from urban centers with services would have more dependence on the natural environment, which should carry a higher knowledge on its uses.

There is the possibility that because people from the Islas Caracas are desegregated in small groups meanly away from each other, the flux of information between them results interfered or is not taking place adequately, hence it part of the popular knowledge would be lost, which results contrary between El Congrio and La Morena, where people are more concentrated.

\section{Conclusion}

The socioeconomic aspects reported in this work are similar to those obtained by other authors in coast communities of the region, where fishing is the main economic activity, suggesting a common pattern in respect to the life level of the artisanal fishermen of the state of Sucre.

New uses of the fishes were reported, which reinforces the importance of this type of studies in the enriching of the scientific knowledge and helping, besides, bioprospection.

It was proven that elderly people in the studied localities present higher knowledge in the ethnoicthyologic nes los habitantes de comunidades semi aisladas del Parque nacional Mochima ubicados en este grupo etario, para tener un amplio conocimiento de los usos de los peces, pareciera estar reflejándose deficiencias en la transmisión del conocimiento popular entre generaciones. De esta manera, se reitera la importancia del presente trabajo en el mantenimiento del conocimiento popular sobre los peces, un valor cultural significativamente relevante en la zona.

En relación con la comparación del conocimiento etnoictiológico respecto a las localidades, se agruparon todos los asentamientos de Las Caracas y se compararon con los del enclave El Congrio-La Morena. Los resultados indican la existencia de diferencias significativas entre ambos sectores $(p<0.05$; $W=3172.0 ; P=0.0059707$ ), a pesar de que en ambas hay carencia o inexistencia de centros deasistencia médica.

Los pobladores del Congrio-La Morena demostraron tener más conocimiento sobre los usos de los peces que los habitantes de las Islas Caracas. Esto resulta un poco contradictorio, pues generalmente se espera que mientras más alejadas estén las localidades de centros urbanos con servicios mayor será su dependencia del medio natural, lo cual debería conllevar a un mayor conocimiento sobre sususos.

Es posible que por estar los pobladores de las Islas Caracas disgregados en pequeños grupos medianamente alejados entre sí, el flujo de información entre ellos resulte interferido o no se esté dando adecuadamente, por lo que se estaría perdiendo parte del conocimiento popular, lo que resulta contrario entre los poblados de El Congrio y La Morena donde los habitantes están más concentrados.

\section{Conclusión}

Los aspectos socioeconómicos reportados en este trabajo son similares a los obtenidos por otros autores en comunidades costeras de la región, donde la pesca es la actividad económica principal, sugiriendo un patrón común respecto al nivel de vida de los pescadores artesanales del estado Sucre.

Fueron reportados nuevos usos de los peces, lo cual refuerza la importancia de este tipo de estudios en el enriquecimiento del saber científico y ayudando, además, en la bioprospección.

Se constató que los pobladores de mayor edad en las localidades estudiadas presentan mayor conocimiento etnoictio- 
knowledge than young people, causing this traditional wisdom to be threatened in their permanence in time, hence the execution of similar works is necessary, covering a higher geographic area, in order to leave a record in that regard.

\section{Acknowledgements}

The authors wish to thank the inhabitants of the fishing communities of the Mochima National Park for their collaboration by giving necessary information for this study.

They would also like to thank the Fondo Nacional de Investigaciones Científicas y Tecnológicas (FONACIT) for the financing to perform this study as part of the re- search project No. 2012000089. lógico que los jóvenes, pudiendo estar amenazada la permanencia en el tiempo de estos saberes tradicionales, por lo que se hace necesaria la ejecución de trabajos similares, que abarquen un mayor ámbito geográfico, con el objeto de dejar un registro escrito al respecto.

\section{Agradecimientos}

Los autores agradecen a los habitantes de las comunidades pesqueras del Parque Nacional Mochima por su colaboración al brindar la información necesaria para el estudio.

También agradecen al Fondo Nacional de Investigaciones Científicas y Tecnológicas (FONACIT) por el financiamiento para la realización de este estudio, como parte del proyecto de investigación № 2012000089.

\section{References}

Adeodato, S. 1997. Os santos reméidos do mar. Globo Ciência 20-25.

Almeida, C. and Albuquerque, U. 2002. Uso de plantas e animaismedicinais no estado de Pernambuco (Nordeste do Brasil): Umestudo de caso. Interciencia 27: 276-284. http://www.redalyc.org/pdf/339/33906902.pdf

Alves, R. and Rosa, I. 2006. From cnidarians to mammals: The use of animals as remedies in fishing communities in NE Brazil. Journal of Ethnopharmacology, 107: 259-276. http://www.sciencedirect.com/science/article/pii/ S0378874106001322?via\%3Dihub

Begossi, A. and Braga, F. 1992. Foodtaboos and folk medicine amongfishermenfromthe Tocantins River (Brazil). Amazoniana, 12: 101-118. https://www.researchgate.net/profile/Alpina Begossi/publication/285161360 Food taboos and folk medicine among fishermen from the Tocantins River/links/57324b2808ae9ace84047e0b/ Food-taboos-and-folk-medicine-among-fishermen-from-the-Tocantins-River.pdf

Branch, L. and Silva, M. 1983. Folk medicine in Alter do Chao, Pará, Brazil. Acta Amazónica, Manaus, 13: $737-$ 797. DOI: http://dx.doi.org/10.1590/1809-4392135737. http://www.scielo.br/scielo.php?pid=S004459671983000600737\&script=sci abstract

Cervigón, F. 1991. Los Peces Marinos de Venezuela. Vol. I. Segunda edición Fundación Científica Los Roques. CromotipCaracas, Venezuela.

Cervigón, F. 1993. Los Peces Marinos de Venezuela. Vol. II. Segunda edición. Fundación Científica Los Roques Cromotips, Caracas, Venezuela.

Cervigón, F. 1994. Los Peces Marinos de Venezuela. Vol. III. Segunda edición. Fundación Científica Los Roques. ExLibris, Caracas, Venezuela.

Cervigón, F. 1996. Los Peces Marinos de Venezuela. Vol. IV. Segunda edición. Fundación Científica Los Roques. ExLibris, Caracas, Venezuela.

Cervigón, F. 2005. La ictiofauna marina de Venezuela: una aproximación ecológica. Boletín Instituto Oceanografico de Venezuela, 44: 3-28. http://www.ojs.udo.edu.ve/index.php/boletiniov/article/view/548

Cervigón, F. and Alcalá, A. 1999. Los Peces Marinos de Venezuela. Vol. V. Segunda edición. Fundación Museo del Mar, Fondo Editorial del Estado Nueva Esparta, Venezuela.

Cervigón, F. and Gasparini, P. 1989. Islas de Venezuela. Editorial Arte. Caracas, Venezuela. 
Costa-Neto, E. 1999. "Barata é um santo remédio": introdução à zooterapia popular no estado da Bahia.Universidade Estadual de Feira de Santana. Feira de Santana.

Costa-Neto, E. 2001. A cultura pesqueira do litoral norte da Bahia: etnoictiologia, desenvolvímento e sustentabilidade. Editora de la Universidad de Bahia/Editora Universidad Federal de Alagoas: Salvador/Maceió, Brasil.

Fariña, A. and Méndez, E. 2009. Variación estacional de la estructura comunitaria de peces en dos arrecifes: rocosocoralino y de octocorales, en el Bajo Las Caracas, Venezuela. Revista de Biología Marina y Oceanografía 44: 153-162. DOI: http://dx.doi.org/10.4067/S0718-19572009000100015 http://www.scielo.cl/scielo. php?script=sci arttext\&pid=S0718-19572009000100015

Fariña, A., Ruiz-Velásquez, L., Rojas, M. Peñuela, J. and González, M. 2011. Etnobiología marina y aspectos pes- queros en seis comunidades pesqueras de la Península de Paria, Venezuela. Interciencia 36: 256-264. http://www. redalyc.org/articulo.oa?id=33917994003

Febres, G. 1974. Circulación de las aguas superiores de la fosa de Cariaco en abril de 1979. Boletín del Instituto Oceanográfico de Venezuela 13: 79-86.

Field-Cortazares, J., Calderón-Campos, R. and Seijo-y-Moreno, J. 2009. Envenenamiento por pez globo. Boletín Clínico del Hospital Infantil del Estado de Sonora, 26: 28-32. http://www.medigraphic.com/pdfs/bolclin- hosinfson/bis2009/bis091f.pdf

Freites, C. 2004. Etnobotánica en cuatro comunidades de la costa norte de la Península de Paria, Estado Sucre, Venezuela. Trabajo de pregrado. Departamento de Biología, Universidad de Oriente, Cumaná.

Humann, P. and Deloach, N. 2002. Reef fish identification. Florida, Caribbean, Bahamas. New WorldPublications, Inc. Jacksonville, Florida.

INPARQUES. 1982. Guía de los Parques Nacionales y Monumentos Naturales de Venezuela. Ediciones Fundación de Educación Ambiental, Caracas.

INSOPESCA. 2011. Estadísticas pesqueras de Venezuela 2010. Institito Socialista de Pesca y Acuicultura, Ministerio de Agricultura y Tierras, Caracas.

López, J. 2011. "El hueso de la corvina u otolito. Un amuleto de posible origen protohistórico". Diariodecadiz.es. http://www.gentedelpuerto.com/2011/12/05/1-219-el-hueso-de-corvina-u-otolito-un-amuleto-de-posibleorigen-protohistorico/

Marcano, M. 2003. Etnobotánica en nueve comunidades litorales de la costa norte de la Península de Paria, Estado Sucre, Venezuela. Trabajo de pregrado. Departamento de Biología, Universidad de Oriente, Cumaná.

Martínez, G. 2004. "Aspectos socioeconómicos del centro poblado Santa Fe, Municipio Sucre, Estado Sucre". http:// www.monografias.com/trabajos-pdf4/eia-estudio-socioeconomico-comunidad-santa-fe/eia-estudio-socioeconomico-comunidad-santa-fe.pdf

Nascimiento, J. and Costa-Neto, E. 2005. Primeiro registro de utilização medicinal de recursos pesqueiros na cida de de São Félix, Estado da Bahia, Brasil. Maringá, 27: 177-183. DOI: http://dx.doi.org/10.4025/actascibiolsci.v27i2.1328 http://periodicos.uem.br/ois/index.php/ActaSciBiolSci/article/view/1328

Novoa, R. 2000. La pesca en el Golfo de Paria y Delta del Orinoco costero. Editorial Arte. Caracas, Venezuela.

Okuda, T. 1978. Condiciones hidrográficas de las aguas superficiales de la Fosa de Cariaco y áreas adyacentes. Boletín del Instituto Oceanográfico de Venezuela 21: 3-12.

PARKSWATCH. 2004. "Parque Nacional Mochima". http://www.parkswatch.org/parkprofile.php?l=spa\&country=ven \&park=monp\&page $=$ phy $(20 / 01 / 2011)$.

Royero, R. 1989. Contribución al conocimiento de la etnoictiología Piaroa (Dearuwa). Antropológica / Wilbert, Werner 72 : 61-75. http://www. fundacionlasalle.org.ve/userfiles/Ant\%201989\%20No \%2072\%20p\%2061-75.pdf

Royero, R. 1994. Algunos aspectos de la etnoictiología y la historia natural de los Yanomami del Alto río Siapa y río Mavaca, Estado Amazonas, Venezuela. Antropológica / Wilbert, Werner 84: 73-96. http://www.fundacionlasalle.org.ve/userfiles/Ant\%201994-1996\%20No\%2084\%20p\%2073-96.pdf

Silvano, R. and Begossi, A. 2002. Ethnoichthyology and fish conservation in the Piracicaba river (Brazil). Journal of Ethnobiology 22: 285-306. https://ethnobiology.org/sites/default/files/pdfs/JoE/22-2/SilvanoBegossi2002.pdf 
Souza, M. and Barrella, W. 2001. Conhecimento popular sobre peixes numa comunidade Caiçara da Estação Ecológica de Juréialtatins (SP). Boletim do Instituto de Pesca 27: 123-130. http://www.pesca.sp.gov. br/27\%5B2\%5Dart-01.pdf

Thé, A. 2002. Estudo sobre o regime de propriedade comum em duas comunidades de pescadores do Rio São Francisco, MG. En: IV Simpósio Brasileiro de Etnobiologia e Etnoecologia, 25/02 a 01/03/2002 Livro de Resumos. Recife/PE. 29 p.

Velásquez, E. 2003. Etnobotánica en la comunidad de Campoma, Estado Sucre, Venezuela. Trabajo de pregrado. Departamento de Biología, Universidad de Oriente, Cumaná.

Villarroel, E., Buitrago, E. and Lodeiros, C. 2004. Identificación de factores que afectan el crecimiento y la supervi- vencia de Crassotrea rhizophorae (Mollusca: Bivalvia) bajo condiciones de cultivo suspendido. Revista Cientí- fica Facultad de Ciencias Veterinarias 14: 1-12. http://www.redalyc.org/html/959/95911219005/

Cite this paper/Como citar este artículo: Ruiz-Velásquez, L., Fariña, A., Rojas, M., Alió, J. (2017). Ethnoichthyology and fishery aspects of persons inhabiting fishery communities at Mochima National Park, Sucre State, Venezuela. Revista Bio Ciencias 21 pages, Article ID: 04.05.03. http://dx.doi.org/10.15741/revbio.04.05.03 